\title{
Tulane
}

Tulane Economics Working Paper Series

\section{In the Land of OZ: Designating Opportunity Zones}

\author{
James Alm \\ Tulane Economics \\ jalm@tulane.edu
}

\author{
Trey Dronyk-Trosper \\ Amazon \\ treyldt@gmail.com
}

Working Paper 2006

September 2020

\author{
Sean Larkin \\ Tulane University \\ slarkin@tulane.edu
}

\begin{abstract}
The Tax Cuts and Jobs Act of 2017 allowed governors of the fifty states to designate low-income areas as a "Qualified Opportunity Zone" (QOZ), which entitled the investors in these QOZs to significant tax incentives. As a result, each governor's designation of QOZs provided an opportunity for the governor to introduce investments in low-income communities that would, in principle, increase economic opportunities in these areas. At the same time, each governor's decision also provided an opportunity for the governor to reward political allies, to buy voter support, and to help business interests. Which of these many factors influenced the designation of QOZs? In this paper we estimate the impact of economic and political variables on the governors' decisions to choose which areas among all eligible areas would receive QOZ status and which would not. We find that the QOZ selection process overall seems to have been relatively technocratic, with many of the strongest factors that determine QOZ designation being indicators of economic distress such as higher rates of unemployment, welfare receipt, or lower median income, all of which are consistent with the presumed goals of QOZs. Even so, we also find that political factors are significant in QOZ designation, with Democratic representation being negatively associated with QOZ nomination and with political representation by a local politician of the same party as the governor being positively associated with QOZ nomination. Of some note, we also find that areas with higher college attainment are favored.
\end{abstract}

Keywords: Opportunity zones, Tax incentives, Place-based development policies. JEL codes: H24, I38, O23, R38. 


\title{
In the Land of OZ: Designating Opportunity Zones
}

\author{
James Alm, Trey Dronyk-Trosper, and Sean Larkin*
}

\begin{abstract}
The Tax Cuts and Jobs Act of 2017 allowed governors of the fifty states to designate low-income areas as a "Qualified Opportunity Zone" (QOZ), which entitled the investors in these QOZs to significant tax incentives. As a result, each governor's designation of QOZs provided an opportunity for the governor to introduce investments in low-income communities that would, in principle, increase economic opportunities in these areas. At the same time, each governor's decision also provided an opportunity for the governor to reward political allies, to buy voter support, and to help business interests. Which of these many factors influenced the designation of QOZs? In this paper we estimate the impact of economic and political variables on the governors' decisions to choose which areas among all eligible areas would receive QOZ status and which would not. We find that the QOZ selection process overall seems to have been relatively technocratic, with many of the strongest factors that determine QOZ designation being indicators of economic distress such as higher rates of unemployment, welfare receipt, or lower median income, all of which are consistent with the presumed goals of QOZs. Even so, we also find that political factors are significant in QOZ designation, with Democratic representation being negatively associated with QOZ nomination and with political representation by a local politician of the same party as the governor being positively associated with QOZ nomination. Of some note, we also find that areas with higher college attainment are favored.
\end{abstract}

Keywords: Opportunity zones, tax incentives, place-based development policies.

JEL Codes: H24, I38, O23, R38.

\section{Acknowledgments}

We are grateful to Peter Leeson and an anonymous referee for many helpful comments and suggestions.

\section{Declarations}

The authors declare no conflicts of interest. All data and code used in this paper are available upon request.

* Tulane University, Department of Economics, Tilton Hall, New Orleans, LA 70118 (Alm jalm@tulane.edu; Dronyk-Trosper treyldt@gmail.com; Larkin slarkin@,tulane.edu). Please address all correspondence to James Alm. We are grateful to Peter Leeson and an anonymous referee for many helpful comments and suggestions. 


\section{Introduction}

An important if somewhat overlooked feature of the Tax Cuts and Jobs Act (TCJA) of 2017 was the creation of the "Opportunity Zone" (OZ) program. An OZ is a designated lowincome area within a state, selected by the governor of the state from census tracts in the state that meet specified eligibility requirements, with investments in an OZ then eligible for a range of generous tax incentives. At the time the TCJA was signed into law on 22 December 2017, the national unemployment rate was 4.1 percent, and the overall poverty rate was 12.3 percent. However, these national rates mask enormous heterogeneity across census tracts. The presumed intention of the $\mathrm{OZ}$ incentives was to encourage investment in these low-income areas in order to improve incomes, jobs, and economic development in areas that were seen as lagging behind in opportunities, especially opportunities for minority groups. In this paper we estimate the impact of economic and political variables on the governors' decisions to choose which areas among all possible areas would receive OZ status and which would not.

In the specific case of OZs, these tax incentives are of several types, of which the main ones relate to the treatment of realized capital gains on the investments. As discussed in more detail later, there is a temporary deferral of realized capital gains from a sale of an investment outside of an $\mathrm{OZ}$ investment, if the realized gains are reinvested in an OZ. Also, there is a step up in basis of 10 percent if the investment stays in the $\mathrm{OZ}$ for 5 years and a step up in basis of 15 percent if the investment is held for 7 years. Finally, all capital gains from the sale of an investment in an OZ are excluded from taxable income if the investment is held for at least 10 years. In their entirety, these tax incentives create significant tax breaks for investors, tax breaks that are of more value to higher income investors. 
The TCJA specified two criteria that census tracts had to meet to qualify for these incentives, thereby receiving a special "Qualified Opportunity Zone" (QOZ) designation. To be designated, each potential QOZ must meet one of two criteria. First, the poverty rate in the census tract must be at least 20 percent. Second, the median family income in the census tract must be less than or equal to 80 percent of either the statewide median family income or the metro family median income (where applicable), whichever is higher. The governor of each state can then nominate up to 25 percent of these "low-income census" (LIC) tracts in the state as a QOZ, and up to 5 percent of all QOZs nominated can be non-LICs if these census tracts are geographically contiguous with an LIC. This process was a one-time process that was completed before the end of 2018, and in December 2018 the U.S. Treasury finalized its certification of QOZs.

In total, Treasury designated $8764 \mathrm{OZs}$ in the fifty states and in Washington, D.C., Guam, Northern Mariana Islands, Puerto Rico, Samoa, and the Virgin Islands, from 42,160 potential census tracts out of a nationwide total of 74,163 census tracts. ${ }^{1}$ All tracts that were nominated by the governor and subsequently certified by the Secretary of the U.S. Treasury become designated OZs, and investors in these OZs become eligible for the tax incentives. As a result, each governor's designation of OZs provided an opportunity for the governor to introduce investments in lowincome communities that will, in principle, increase economic opportunities in these areas. However, because investments held in an $\mathrm{OZ}$ for more than ten years can avoid virtually all taxes

\footnotetext{
${ }^{1}$ The various government regulations for OZs include, among others: "Investing in Qualified Opportunity Funds", available online at https://www.federalregister.gov/documents/2018/10/29/2018-23382/investing-in-qualifiedopportunity-funds; "Investing in Qualified Opportunity Funds", available online at: www.federalregister.gov/documents/2019/05/01/2019-08075/investing-in-qualified-opportunity-funds; “Treasury, IRS issue proposed regulations on new Opportunity Zone tax incentive", available online at https://www.irs.gov/newsroom/treasury-irs-issue-proposed-regulations-on-new-opportunity-zone-tax-incentive; and "Special Rules for Capital Gains Invested in Opportunity Zones", available online at https://www.irs.gov/pub/irsdrop/rr-18-29.pdf. See also Novogradic (2018), Eastman and Kaeding (2019), Nitti (2019), Tankersley (2019), and Tax Policy Center (2019) for useful information.
} 
on new capital gains, there are strong incentives both to invest in OZs and also to exploit this tax avoidance mechanism. As a result, each governor's decision also provided an opportunity for the governor to reward political allies, to buy voter support, and to help business interests. Perhaps as a result, opportunity zones have faced increased criticism about the politicization of QOZ designation $^{2}$, including unintended consequences ${ }^{3}$ and anticipated failures ${ }^{4}$ of OZ designation, and these criticisms have even made their way into recent high-profit entertainment programs. ${ }^{5}$ Indeed, as discussed later, our tabulations demonstrate that 38 of the 8764 QOZs do not appear to meet the Treasury Department's guidelines for QOZ designation, suggesting a failure in the nomination process. Some politicians have already begun crafting bills to address these criticisms and even to advocate the complete dissolution of the $\mathrm{OZ}$ program. ${ }^{6}$

The tax incentives included in OZs are similar to a range of "place-based development policies" that have been utilized over the years. In the United States, these place-based development policies include programs like Enterprise Zones, Renewal Communities, Enterprise Communities, the New Market Tax Credit, the Historic Tax Credit, and the Low-income Housing

\footnotetext{
${ }^{2}$ See “A Trump Tax Break To Help The Poor Went To a Rich GOP Donor's Superyacht Marina”, available online at https://www.propublica.org/article/superyacht-marina-west-palm-beach-opportunity-zone-trump-tax-break-tohelp-the-poor-went-to-a-rich-gop-donor. See also "Symbol of '80s Greed Stands to Profit from Trump Tax Break for Poor Areas", available online at https://www.nytimes.com/2019/10/26/business/michael-milken-trumpopportunity-zones.html.

${ }^{3}$ See "Fixing America's Forgotten Places - Opportunity Zones, created by Trump's tax law, are meant to help the heartland thrive and make the country more equal, but can they pull it off?", available online at https://www.theatlantic.com/ideas/archive/2018/07/how-do-we-help-this-place/565862/.

${ }^{4}$ See: "The Problem with Opportunity Zones", available online at https://www.citylab.com/equity/2018/05/theproblem-with-opportunity-zones/560510/; "How a Trump Tax Break to Help Poor Communities Became a Windfall for the Rich", available online at https://www.nytimes.com/2019/08/31/business/tax-opportunity-zones.html; "Trump Tax Break That Benefited the Rich Is Being Investigated", available online at https://www.nytimes.com/2020/01/15/business/trump-opportunity-zone-investigation.html; and "Developers Rushing to Opportunity Zones for Tax Break, But Is It Helping Louisiana's Low-Income Areas?", available online at www.theadvocate.com/new_orleans/news/business/article_0ddb2d22-2576-11e9-bde9837b83173a57.html.

${ }^{5}$ See the episode of the HBO series Billions entitled "Opportunity Zone", in which the character Bobby Axelrod (or Axe) wants to invest in an $\mathrm{OZ}$ in the Yonkers neighborhood in which he grew up.

${ }^{6}$ On 6 November 2019 Sen. Ron Wyden (D-OR) introduced in the U.S. Senate a bill to reform the OZ program. See https://www.finance.senate.gov/imo/media/doc/Opportunity $\% 20$ Zone $\% 20$ Reporting $\% 20$ and $\% 20$ Reform $\% 20$ Act $\% 2$ 0of\%202019\%20Bill\%20Text.pdf.
} 
Tax Credit. There are also place-based policies around the world, such as Structural Funds and Enterprise Zones in the European Union and Special Economic Zones in China, among many other programs. The specific provisions of these many programs vary, but the common feature is the use of targeted incentives that are intended to encourage investment in underperforming areas. There has been much research that has examined the impact of these policies on economic development. Overall, this research has found that the success of these policies is decidedly mixed, both in the United States and abroad (Bartik, 1991, 2003, 2019; Ladd, 1994; Papke 1994; Peters and Fisher, 2002, 2004; Bondonio and Greenbaum, 2007; Billings, 2009; Hanson, 2009; Neumark and Kolko, 2010; Bowers et al., 2011; Ham et al., 2011; Hanson and Rohlin, 2011, 2013; Accetturo and de Blasio, 2012; Gobillon, Magnac, and Selod, 2012; Givord, Rathelot, and Sillard, 2013; Reynolds and Rohlin, 2014; The World Bank, 2015; Jenson 2018). ${ }^{7}$ Indeed, preliminary work on OZs by Chen, Glaeser, and Wessel (2019) and Theodos, González, and Meixell (2020) finds that OZs are not having their hoped-for impacts. However, this research on place-based incentives has seldom examined the factors that determine the selection of specific geographic areas for inclusion in the tax incentive program. ${ }^{8}$ An important and recent exception is Frank, Hoopes, and Lester (2020), who examine the factors associated with QOZ selection. ${ }^{9}$ Like Frank, Hoopes, and Lester (2020), the purpose of our paper is to estimate the impact of political and economic factors on the governors' decisions to choose which eligible census tracts would receive QOZ status and which would not.

\footnotetext{
${ }^{7}$ See Glaeser and Gottlieb (2008), Neumark and Simpson (2014) and Duranton and Venables (2018) for recent and comprehensive surveys of this literature.

${ }^{8}$ An important recent exception is Frank, Hoopes, and Lester (2020), who examine the political processes associated with QOZ selection.

${ }^{9}$ Theodos, Meixell, and Hedman (2018) also examine QOZ selection, although their analysis of QOZ selection relies mainly on simple comparisons of the mean characteristics of OZs that are selected versus those not are designated for QOZ selection. See also Theodos and Meixell (2018), who apply similar methods to the specific case of California.
} 
We collect information on all eligible census tracts in the U.S., and we then estimate a variety of specifications that identify the role of economic and political variables on the QOZ designation. We find that the $\mathrm{OZ}$ selection process overall seems to have been relatively technocratic, with many of the strongest factors that determine $\mathrm{OZ}$ designation being indicators of economic distress such as higher rates of unemployment, welfare receipt, or lower median income. Even so, we also find that political factors are quite significant in QOZ designation, with Democratic representation being negatively associated with QOZ designation and with political representation by a local politician of the same party as the governor being positively associated with QOZ designation. Of some note, we also find that areas with higher college attainment are favored, which is a potential concern because higher educational attainment is positively associated with earning potential and political engagement.

As noted, our work is similar to Frank, Hoopes, and Lester (2020), with several important distinctions. In particular, Frank, Hoopes, and Lester (2020) use a linear probability estimation strategy to focus upon the political processes associated with QOZ selection, including the engagement of external advisors and agencies in the selection process. Our paper expands their modeling to include both the linear probability estimation and logit estimation. Also, we concentrate on identifying in more detail the underlying census tract characteristics that influence QOZ selection, in addition to various political variables like lower and upper house legislative controls. Of note, we use more expansive demographic and education variables in addition to more descriptive political variables, and we also employ a more extensive array of robustness tests. Even so, our estimation results are broadly similar to those of Frank, Hoopes, and Lester (2020).

In the next section, we discuss the details of opportunity zones. We then present our data and methods, followed by our results. We conclude in the final section. 


\section{What is an "Opportunity Zone"? Definitions and tax incentives}

\subsection{Definitions}

To facilitate our discussion, we begin with some basic definitions that define the main features of the OZ program.

A low-income census tract (LIC) is a census tract in which either the poverty rate is at least 20 percent or tracts in which the median family income is less than or equal to 80 percent of the statewide median family income or metro family median income (where applicable), whichever is higher. A related definition is a Treasury-identified census tract, which is a census tract that is contiguous with one or more LICs but which does not meet the LIC criteria.

A state governor may declare 25 percent of the LICs in the state as a Qualified Opportunity Zone (QOZ) based on 2011-2015 ACS 5-year data from the Census Bureau. ${ }^{10}$ Note that 5 percent of all QOZs nominated can be contiguous with an LIC, rather than an LIC itself, as specified by a Treasury-identified census tract. Because of this provision, census tracts adjacent to an LIC, but not necessarily meeting the criteria for QZ nomination, may still be nominated for QOZ status. However, no more than 5 percent of the QOZs that are nominated within each state may be these contiguous tracts.

A Qualified Opportunity Fund (QOF) is a self-certified entity treated as a partnership or corporation for federal tax purposes and organized in any of the 50 states, District of Columbia, or the five U.S. territories for the purpose of investing in qualified opportunity zone property. At least 90 percent (or more) of held assets must be QOZ property.

\footnotetext{
${ }^{10}$ Note that for 51 QOZs nominated late in the process, the 2012-2016 ACS data was used.
} 
A QOZ business is a business with substantially all of its tangible assets located in QOZs. Internal Revenue Service (IRS) regulations require that 70 percent of all tangible property held be in a $\mathrm{QOZ}$, and that 50 percent of the gross income from a QOZ business be derived from active trade or conduct in a QOZ (Internal Revenue Service, 2018). Several enterprises cannot qualify as a QOZ business, including a golf course, a country club, a massage parlor, a hot tub facility, a suntan facility, a gambling facility, and stores specializing in alcoholic beverages to be consumed off the premises. A QOZ business may include houses and apartments for rent.

A QOZ property must be a property purchased after 31 December 2017, be qualified as a QOZ at the time of purchase, and remain qualified for substantially all of the time held. These properties include:

- QOZ Stock: Equity in a QOZ business held by a QOF.

- QOZ Partnership Interest: Partnership interest in a QOZ business held by a QOF.

- QOZ Business Property: Tangible property used in a trade or business in a QOZ if the original use of such tangible property commences with the QOF or the QOF substantially improves the tangible property, where "substantial improvement" means that during any 30-month period additions to the tax basis of the building (excluding land values) are made such that the value added to the tax basis is higher than the adjusted taxpayer basis at the beginning of any 30 -month period.

Note that a 90 percent investment in a business with a 70 percent QOZ business property means that there must be a minimum 63 percent investment in QOZs for a QOF.

\subsection{Tax incentives}

There are three tax incentives from investing in a QOF. First, there is a temporary deferral of realized capital gains from a sale outside of an OZ if reinvested in a QOF, which must be realized (and taxed) when the property is sold or at the end of 2026, whichever occurs first. An investor must invest in a QOF within 180 days of realizing the capital gains to qualify for deferment.

Secondly, capital gains newly invested into a QOF will receive a step-up in basis of 10 percent if the investment is held for 5 years, and another 5 percent (for a total of 15 percent) if held 
for 7 years. This provision enables investors to reduce 15 percent of their capital gains invested into a QOF from taxable income if held for the full 7 years.

Third, there is permanent exclusion from taxable income of capital gains from the sale or exchange of an investment in a QOF if the investment is held for 10 years. This incentive only applies to gains accrued after an investment in a QOF. As a result, capital gains earned before investment in the QOF receive benefits from the first and second tax incentives, while capital gains earned after investing in the QOF benefit from this third incentive.

In their entirety, these tax incentives mean that, for an investment that is held for ten years, all unrealized capital gains used for investment in a QOF will not be taxed until 2026, only 85 percent of the original capital gains invested will be taxed (100 percent would have been if realized originally), and no taxes will be paid on the appreciation of the investment. These represent quite significant tax breaks for investments in a QOF. Given that the marginal tax rate on capital gains varies from 0 percent for low income earners to 20 percent for higher income earners, these tax benefits will be of more value to higher income investors.

As an example that illustrates the magnitude of these benefits, consider the case of an individual facing a 20 percent capital gains tax rate who sells stocks, earns $\$ 1$ million in capital gains on these sales, and then reinvests these capital gains in a QOF that earns $\$ 50,000$ every year. After 6 years, the investor will have made $\$ 1,300,000$ (or the initial $\$ 1,000,000$ in capital gains plus $\$ 300,000$ from the $[6 \times \$ 50,000]$ in returns each year). Selling this QOF in its entirety would result in capital gains taxes on $\$ 300,000$ of earnings, plus $\$ 900,000$ from the original investment due to the step up in basis (e.g., "...if the investment is held in the QOF for 5 years"), thereby reducing the capital gains tax base by $\$ 100,000$. Selling the QOF after 8 years would result in earnings of $\$ 1,400,000$ but capital gains taxes on only $\$ 850,000$ of the original investment plus 
the $\$ 400,000$ in newly earned capital gains (e.g., “...if the investment is held in the QOF for 5 years, up to a total of 15 percent if the investment is held in the QOF for 7 years"), reducing the capital gains tax base by $\$ 150,000$. However, selling the investment in year 11 would result in capital gains taxes on only the initial amount less the 15 percent reductions because of the permanent exclusion of capital gains from holding the investment for 10 years (e.g., "...there is permanent exclusion from taxable income of capital gains from the sale or exchange of an investment in a QOF if the investment is held for 10 years"). All of accumulated capital gains from the QOF investment would avoid the 20 percent capital gains tax rate, and only $\$ 850,000$ of the initial \$1 million in capital gains would be subject to the capital gains tax rate, and any additional capital gains earned would be received tax free.

\section{Data and methods}

Our data come from several sources. First, our data on designated opportunity zones and all LICs (including Treasury-identified census tracts) come from the U.S. Department of the Treasury Community Development Financial Institutions Fund. Demographic and economic data come from the American Community Survey (ACS) five year survey of 2011-2015. ${ }^{11}$ The ACS data include information at the census tract level on counts of sex, age, race, median house value, median household income, population, employment status (including the unemployment rate), educational attainment, and public assistance recipients. The ACS data also contain information on median income at the county and state levels. We aggregate the county-level income data to the metropolitan level by using a county-metropolitan area crosswalk provided by the National Bureau of Economic Research. We use this information to construct economic and demographic

\footnotetext{
${ }^{11}$ Note that there are more recent ACS data from the 2012-2016 survey. We use the ACS data from the 2011-2015 survey because these are the data that were available at the time of QOZ designation by the governors of the states.
} 
variables at the census tract level, including: Median House Value, Unemployment Rate, Median Household Income, Proportion with Less Than High School Diploma, Proportion with 4-year Degree, Proportion Black, Proportion Hispanic, Proportion Native American, Proportion Under 18, Proportion Over 65, and Proportion on Welfare.

We also obtain data on institutions of higher learning from the Census of Institutions of Higher Learning taken from the U.S. Department of Homeland Security Homeland Infrastructure Foundation Level Data. We use this information to construct a dummy variable Higher Education Campus, equal to 1 if there is an institution of higher learning located in a census tract and 0 otherwise. We include this variable on college campus locations because locations with college campuses may more easily meet the LIC requirements since students can be included in the poverty rate calculations. ${ }^{12}$ We also create a dummy variable In Metropolitan Area, equal to 1 if the census tract is located in a metropolitan area and 0 otherwise.

For political variables, we use data from Ballotpedia and state legislator websites to match both upper and lower house state legislators and their party affiliations to each QOZ tract, using representatives listed at the time of OZ nomination in March 2018. From the same datasets, we also include governor party affiliation at the same date. Since governors are the final arbiters of deciding which OZs will be nominated, it is important to control for potential partisan selection. This procedure allows us to create several variables that examine the representation of each census tract in the state legislature. The first two variables measure the percent of the census tract represented by Democrats in the lower or upper chamber of the legislature (Percent of Tract Represented by Democrat (Lower) and Percent of Tract Represented by Democrat (Upper)). The

\footnotetext{
${ }^{12}$ For example, see “Opportunity Zones Knock Where They're Needed Least”, available online at https://www.wsj.com/articles/opportunity-zones-knock-where-theyre-needed-least-11568412633. See also Gelfond and Looney (2018). We are grateful to an anonymous referee for this suggestion.
} 
other two variables are dummy variables that measure whether the majority of the geographic area of the census tract is represented by representatives in the lower or upper legislature chamber who are affiliated with the same political party as the current governor (Legislature-Governor Partisan Match (Lower), Legislature-Governor Partisan Match (Upper)). These variables are coded as dummy variables with 1 indicating a match, and 0 otherwise. Because governors select which OZs will be nominated, their relationship with co-partisans and opposing parties may play a role in which OZs they select. Similarly, legislators may lobby the governor for certain tracts in their legislative districts to be nominated, and the governor can reward or punish legislators through the selection of nominated OZs.

Starting with 74,133 census tracts in the entire U.S., we remove tracts in Nebraska (because of its unicameral legislature), and we also drop census tracts outside the continental U.S. (Alaska, Hawaii, and U.S. territories) and in Washington, D.C. This results in a sample size of 71,847 census tracts. This sample size is further reduced to 71,250 because we remove census tracts that are considered unpopulated in the ACS survey. Finally, Median House Value and Median Household Income information are not included for all census tracts, restricting the sample of census tracts to 69,921 . From these 69,921 observations, we then choose the census tracts that are eligible for designation as either a LIC or Treasury-determined census tract. These total 29,549. We call these census tracts Potential QOZs; that is, Potential QOZs are the tracts that could potentially be chosen by the governor of each state. From these Potential QOZs, ultimately 7410 were selected by state governors to receive what we term Designated QOZs. Our goal is to estimate the factors that determine the selection of the 7410 Designated QOZs from the 29,549 Potential QOZs. 
Of the states in the sample, California has the most Designated QOZs (879), followed by Texas (628), New York (514), Florida (427), and Illinois (327); the states with the fewest QOZs are Alaska, Delaware, Hawaii, Montana, North Dakota, Rhode Island, South Dakota, Vermont, and Wyoming, all with 25. The top city locations for Designated QOZs are New York City (306), followed by Los Angeles (274), Chicago (181), Houston (105), and Detroit (94). A map of the location of these QOZs is shown in Figure 1.

Summary statistics of our variables for all census tracts, for Potential QOZs, and for Designated QOZs are given in Table 1. All proportion variables (e.g., Proportion with Less Than High School Diploma) are coded from 0 to 1 , with 1 being 100 percent of the population and 0 being zero percent. Nominal variables like Median House Value and Median Household Income are in thousands of dollars (USD), and Population is measured in thousands. Not surprisingly, Median Household Income and Median House Value are lower in Potential QOZs and Designated QOZs relative to similar measures across all census tracts, and the Unemployment Rate is higher in Potential and Designated QOZs relative to the national average. Also, the proportion of the census tract with a college degree is lower for Potential and Designated QOZs than in the U.S. on average, while the Proportion Black is much higher in Potential and Designated QOS than in all census tracts. The Proportion Over 65 years of age is not statistically different in the various census tract measures.

Our estimation strategy then estimates the factors that determine the choice of Designated QOZs from all possible Potential QOZs. We follow the public choice literature by estimating the impact of economic and political variables on the selection of Designated QOZs from all Potential QOZs, using the following model: ${ }^{13}$

\footnotetext{
${ }^{13}$ For a comprehensive recent survey of the empirical literature on the impact of economic and political variables on a wide range of outcomes, see Potrafke (2018); for an earlier but still useful survey, see Besley and Case (2003). See
} 


$$
Q_{O_{i}}=\beta+\alpha \text { Demographic }_{i}+\gamma \text { Political }_{i}+\delta \text { Metropolitan }_{i}+\theta \text { State }_{i}+\varepsilon_{i}
$$

where $Q O Z_{i}$ is a dummy variable equal to 1 indicating a census tract that was designated by the governor of the state and approved by the U.S. Treasury as a Designated QOZ, and 0 indicating a QOZ that met Treasury guidelines but was not designated as an OZ. The variables Demographic , $_{\text {, }}$ Political $_{i}$, and Metropolitan $i$ represent demographic, political, and metropolitan dummy control variables, respectively. Finally, State $_{i}$ includes state specific dummy variables that control for time invariant, state-specific effects between census tracts in each state. Equation (1) is estimated via logit and linear probability (LP) models, with standard errors clustered at the state level.

It should be noted again that our approach is similar in some respects to the approach of Frank, Hoopes, and Lester (2020). However, there are some significant differences in estimation methods, variable definitions, and model specifications, even aside from minor differences like our use of the unemployment rate versus their use of the employment rate. For example, they include the poverty rate in a census tract as an explanatory variable; we do not include this variable because the poverty rate is in fact one of the two criteria for QOZ designation and its inclusion as an explanatory variable may lead to biased coefficient estimates. For demographic controls, they include only the percent of a census tract that is white, while we include a much richer array of demographic controls, including age variables. For education controls, they include only the percent with at least a high school education; we include this variable as well as the Proportion with At Least 4-year Degree. Geographic controls differ across the two studies, including our use of a variable that measures the presence of a higher education campus. Of special note, Frank, Hoopes, and Lester (2020) include only a measure of lower state house partisanship, along with

especially empirical papers on the role of economic and political variables in state government policy decisions, including Alt, Lessen, and Skilling (2002), Chang, Kim, and Ying (2009), Alm and Rogers (2011), Fredriksson, Wang, and Warren (2013), Pickering and Rockey (2013), Joshi (2015), Beland and Oloomi (2017), and Hill and Jones (2017). 
variables that attempt to capture the process by which QOZ designation occurs; we include a similar measure of lower house partisanship along with additional measures of upper house partisanship and of legislature-governor partisanship. Even so, our estimation results are broadly similar to those of Frank, Hoopes, and Lester (2020).

\section{Results}

Logit regression results are presented in Table 2, and LP regressions are given in Table 3. Models 2, 4, 6, and 8 include state fixed-effects, while models 1, 3, 5, and 7 exclude state fixedeffects. Also, models 3, 4, 7, and 8 include contiguous OZs in the sample. Our preferred specifications are models 4 (logit) and 8 (LP).

Looking at economic variables first, we find that census tracts with a higher proportion of population unemployed are statistically insignificant but positively correlated with $\mathrm{OZ}$ selection. The proportion of welfare recipients is significant predictor of $\mathrm{OZ}$ designation, with a 1 percentage point increase in welfare recipients leading to a 0.37 to 0.42 percentage point increase in $\mathrm{OZ}$ designation likelihood. Median household income is negatively and significantly correlated with $\mathrm{OZ}$ designation, and an increase in the median household income of a census tract of 10 percent decreases the likelihood that it is designated as a QOZ by 1.4 to 1.5 percentage points. These results are similar to Frank, Hoopes, and Lester (2020).

We estimate that rural and micropolitan tracts are favored in QOZ designation over metropolitan tracts, as can be seen by the negative and significant coefficient on In Metropolitan Area. Across all specifications, being in a metropolitan area decreases the likelihood of QOZ designation by about 8 percentage points. We also find that, as the share of the population over 65 increases, a census tract is less likely to be selected as an OZ. The coefficient on Proportion Over 
65 is relatively large in magnitude compared to the other estimated coefficients; however, the small differences in this variable across census tracts implies that this variable is relatively unimportant for QOZ designation. Notably, the proportion of the population below 18 is also negative, but only statistically significant for the logit regression. As for race, the proportion of the population that identifies as Black is positively and significantly associated with QOZ designation, a result that is different than Frank, Hoopes, and Lester (2020), while Proportion Hispanic and Proportion Native American are both negative but insignificant. Census tracts with higher (logged) populations are also more likely to be designated as QOZs.

Perhaps surprisingly and importantly, census tracts with higher rates of college diploma attainment are more likely to be designated as a QOZ. An increase of 1 percentage point in the percentage of the population with at least a bachelor's degree increases the likelihood that the tract is designated as a $\mathrm{QOZ}$ by 0.16 to 0.18 percentage points. The relatively large impact from increasing bachelor's degrees may indicate that QOZs are being selected at least partially based on expected future gentrification. As Rosenthal (2007) notes, increasing social capital in neighborhoods is a significant predictor of gentrification, and our evidence that QOZ designations are more likely to be associated with whether a tract is an "up-and-coming" area over census tracts with less rosy future expectations is consistent with Rosenthal (2007). Indeed, we also find that designated OZs are more likely to have an institute of higher learning within their borders. A census tract with a degree granting institution has an increased designation likelihood between 7.9 and 8.8 percentage points. ${ }^{14}$

These results are largely consistent with the intended purpose of the OZ program; that is, our results indicate that the designation process tended to favor those communities with more

\footnotetext{
${ }^{14}$ See also Papke (1994) for a similar result on gentrification.
} 
unfavorable economic conditions, even though the selection process also seemed to favor OZs with higher future growth expectations.

Even so, our estimation results also demonstrate that political variables matter in important ways. A census tract that has a higher proportion of representation by Democrats in the state lower legislative chamber is negatively and significantly associated with $\mathrm{QOZ}$ designation, while increased representation by Democrats in the upper legislative chamber is negatively but not significantly correlated with QOZ designation. For every additional percentage point of a census tract represented by a Democrat, the $\mathrm{OZ}$ is 0.02 percentage points less likely to be designated a QOZ. Further, a tract mostly represented by politicians in the state lower legislative chamber that are in the same party as the state executive is positively and significantly associated with QOZ designation, increasing the likelihood of designation by 2.7 percentage points. Also, a matching of parties in the upper legislature has a positive even if insignificant impact on QOZ designation. Frank, Hoopes, and Lester (2020) also tend to find that partisan matching increases the likelihood of QOZ designation. Such partisan matching may be indicative of governors acting to reward members of their own party through nominating OZs within selected members' legislative districts. This combination of results implies that governors are more responsive to lower house representative partisanship compared to the legislative upper house. This result likely represents the fact that lower house legislators generally represent smaller populations and thus may be more sensitive to any policy impacts at the census tract level than upper house legislators.

Additionally, we test for whether there is heterogeneity in these coefficients based on governor partisanship. To do this, we estimate separate regressions based on whether the state governor identifies as Republican or Democratic. These results are in Table 4. While both Republican and Democratic governors react similarly to the presence of higher education 
institutions, metropolitan census tracts, and median household income, partisanship is correlated with different responses on other variables. Republican governors are more likely to designate OZs with higher proportions of non-high school graduates, while Democratic governors are more likely to designate a census tract as a QOZ if the tract contains more 4-year degree holders. Both of these effects are nearly the same size in magnitude, with a one percentage point increase in each demographic leading to a 0.21 percentage point increase in the likelihood of QOZ designation. In addition, for Republican governors, increasing proportions of either Hispanic or Native American populations result in a lower likelihood of census tract selection. A one percentage point increase in these populations leads to a reduction in selection likelihood of 0.22 and 0.21 percentage points, respectively. Note that average population proportions of Native Americans are relatively low, at about 1 percent across low-income census tracts. In contrast, there is a much higher average proportion of the Hispanic population across census tracts of between 22 and 23 percent. In combination with a high standard deviation for Proportion Hispanic in LIC tracts, our estimation results imply that Republican governors are relatively sensitive to Hispanic concentrations in their QOZ designation. As for Proportion Black, the proportion of Black residents in a census tract is no longer statistically significant for either Democratic or Republican governors.

Note that we have estimated a wide range of alternative specifications as robustness tests. For some state legislatures, districts vote for multiple representatives. Since there is no way to divide census tracts in these areas between the representatives, we run a restricted model with just those census tracts that have a single representative. Table 5 shows the results for both logit and LP estimations. Our coefficient estimates are largely unchanged in both sign and magnitude, with exception of a negative and statistically significant sign on the proportion of census tracts 
represented by Democrats in the state's upper house. This result implies that multiple representatives for one district reduce the impact of upper house senator partisanship.

In other unreported results, we have included a variable intended to rank census tracts on the amount of investment flows that they have recently received, a variable constructed by Theodos, Meisell, and Hedman (2018) and used by Frank, Hoopes, and Lester (2020), and we find that this variable has a small and positive impact on QOZ designation; our other results are not affected. We have also identified what we term "Suspicious" QOZs, or census tracts that do not meet the stated criteria for Designated QOZ status but are so designated anyway. Tables 6 and 7 give information on these Suspicious QOZs. These tracts differ significantly from the "typical" Designated QOZ, with higher income and lower poverty rates that do not meet the official criteria. Also, these Suspicious QOZs have half the rate of welfare recipients, they are less likely to be in a metropolitan area, and they are less likely to be represented by a Democrat. Even so, omitting these Suspicious QOZs from our various estimations does not affect our earlier results in any significant way, and we do not report these results. ${ }^{15}$

\section{Conclusions}

On the whole, the QOZ selection process seems to have been relatively technocratic, with many of the strongest factors being indicators of economic distress such as greater unemployment, more welfare recipients, and lower median household income. Median household income in particular is a significant predictor of QOZ selection, with a 10 percent increase in median household income reducing the likelihood of selection by 1.4 to 1.5 percentage points. Additionally, we find evidence that QOZ designation is correlated with census tracts that are

\footnotetext{
${ }^{15}$ All estimation results are available upon request.
} 
already experiencing demographic changes visible through the increased presence of college educated individuals, which may in turn lead to higher future incomes and housing wealth through gentrification. ${ }^{16}$

However, we also find that political partisanship is an important consideration. For example, Democratic representation in a census tract is negatively associated with QOZ designation (a 0.02 percentage point decrease in QOZ designation for every additional percent of a tract represented by a Democrat), and political representation by a local politician of the same party as the governor is positively associated with QOZ designation (a 0.03 percentage point increase when affiliation is shared), effects that are largely restricted to lower house representatives. Further, we find partisan effects that vary by governor partisanship, and, while median household income, population, metropolitan location, and the existence of a higher education institution all have relatively similar impacts across states, the impact of demographic variables is very different across Republican- versus Democratic- governed states. Republican governors are more likely to designate QOZs with lower levels of education (a 0.2 percentage point increase for every additional percent of the population without a high school diploma), and they are less likely to designated QOZs with higher Hispanic or Native American populations. Democratic governors are 0.2 percentage points more likely to select QOZs for every additional percent of the population with a 4-year degree.

\footnotetext{
${ }^{16}$ Papke (1994) and Rosenthal (2007) discuss this channel in more detail. See also Layser (2019) for a recent analysis that emphasizes legal issues.
} 
In short, it seems clear that it is difficult to separate political considerations from a program intended to help poorer communities. Whether these political considerations ultimately affect the outcomes of the $\mathrm{OZ}$ program remains to be determined. ${ }^{17}$

\section{References}

Accetturo, A., \& de Blasio, G. (2012). Policies for local development: An evaluation of Italy's "Patti Territoriali". Regional Science and Urban Economics, 42, 15-26.

Alm, J., Dronyk-Trosper, T., \& Larkin, S. (2020). Do opportunity zones work? Department of Economics Working Paper. New Orleans, LA: Tulane University.

Alm, J., \& Rogers, J. (2011). Do state fiscal policies affect state economic growth? Public Finance Review, 39 (4), 483-526.

Alt, J. E., Lassen, D. D., \& Skilling, D. (2002). Fiscal transparency, gubernatorial approval, and the scale of government: Evidence from the states. State Politics and Policy Quarterly, 2 (3), 230-250.

Bartik, T. J. (1991). Who Benefits from State and Local Economic Development Policies? Kalamazoo, MI: W.E. Upjohn Institute for Employment Research.

Bartik, T. J. (2003). Local economic development policies. Upjohn Institute Working Paper No. 09-91. Kalamazoo, MI: W.E. Upjohn Institute for Employment Research.

Bartik, T. J. (2019). Making Sense of Incentives - Taming Business Incentives to Promote Prosperity. Kalamazoo, MI: W.E. Upjohn Institute for Employment Research.

Beland, L.-P., \& Oloomi, S. (2017). Party affiliation and public spending: Evidence from U.S. governors. Economic Inquiry, 55 (2), 982-995.

Besley, T., \& Case, A. (2003). Political institutions and policy choices: Evidence from the United States. The Journal of Economic Literature, 41 (1), 7-73.

Billings, S. (2009). Do enterprise zones work? An analysis at the borders. Public Finance Review, $37(1), 68-93$.

Board of Governors of the Federal Reserve System (2018). "Community Reinvestment Act (CRA)". Washington, D.C.: Board of Governors of the Federal Reserve System, available online at: www.federalreserve.gov/consumerscommunities/cra about.htm.

Bondonio, D., \& Greenbaum, R. T. (2007). Do local tax incentives affect economic growth? What mean impacts miss in the analysis of enterprise zone policies. Regional Science and Urban Economics, 37 (1), 121-136.

Bowers, K. J., Johnson, S. D., Guerette, R. T., Summers, L., \& Poynton, S. (2011). Spatial displacement and diffusion of benefits among geographically focused policing initiatives: A meta-analytical review. Journal of Experimental Criminology, 7 (4), 347-374.

Chang, C.-P., Kim, Y., \& and Ying, Y.-H. (2009). Economics and politics in the United States: A state-level investigation. Journal of Economic Policy Reform, 12 (4), 343-354.

\footnotetext{
${ }^{17}$ See Alm, Dronyk-Trosper, and Larkin (2020) for estimation results on this issue. See also Chen, Glaeser, and Wessel (2019) and Theodos, González, and Meixell (2020), who find that opportunity zones have had little impact on housing prices and other desired outcomes, at least to date.
} 
Chen, J., Glaeser, E. L., \& Wessel, D. (2019). The (non-) effect of opportunity zones on housing prices. NBER Working Paper No. 26587. Boston, MA: National Bureau of Economic Research.

Duranton, G., \& Venables, A. J. (2018). Place-based policies for development. World Bank Working Paper. Washington, D.C.: The World Bank.

Eastman, Scott, and Nicole Kaeding (2019). "Opportunity Zones: What We Know and What We Don't." Washington, D.C.: The Tax Foundation, available online at: www.taxfoundation.org/opportunity-zones-what-we-know-and-what-we-dont/\#ftn28.

Fredriksson, P. G., Wang, L., \& Warren, P. L. (2013). Party politics, governors, and economic policy. Southern Economic Journal, 80 (1), 106-126.

Frank, M. M., Hoopes, J. L., \& Lester, R. (2020). What determines where opportunity knocks? Political affiliation in the selection of opportunity zones. SSRN Working Paper, available online at: https://ssrn.com/abstract=3534451.

Gelfond, H., \& Looney, L. (2018). Learning from opportunity zones: How to improve place-based policies. Washington, D.C.: The Brookings Institution.

Givord, P., Rathelot, R., \& Sillard, P. (2013). Place-based tax exemptions and displacement effects: An evaluation of the "Zones Franches Urbaines Program". Regional Science and Urban Economics, 43 (1), 151-163.

Glaeser, E. L., \& Gottlieb, J. D. (2008). The economics of place-making policies. Brookings Papers on Economic Activity, Spring, 155-239.

Gobillon, L., Magnac, T., \& Selod, H. (2012). Do unemployed workers benefit from enterprise zones: The French experience. Journal of Public Economics, 96 (9-10), 881-892.

Ham, J. C., Swenson, C., Imrohoroglu, A., \& Song, H. (2011). Government programs can improve local labor markets: Evidence from state enterprise zones, federal empowerment zones, and federal enterprise communities. Journal of Public Economics, 95 (7-8), 779-797.

Hanson, A. (2009). Local employment, poverty, and property value effects of geographicallytargeted tax incentives: An instrumental variables approach. Regional Science and Urban Economics, 39 (6), 721-731.

Hanson, A., \& Rohlin, S. (2011). Do location-based tax incentives attract new business establishments? Journal of Regional Science, 51 (3), 427-449.

Hanson, A., \& Rohlin, S. (2013). Do spatially targeted redevelopment programs spillover? Regional Science and Urban Economics, 43 (1), 86-100.

Hill, A. J., \& Jones, D. B. (2017). Does partisan affiliation impact the distribution of spending? Evidence from state governments' expenditures on education. Journal of Economic Behavior \& Organization, 143, 58-77.

Internal Revenue Service (2018). Opportunity zones frequently asked questions. Washington, D.C.: Internal Revenue Service, available online at: www.irs.gov/newsroom/opportunityzones-frequently-asked-questions.

Jenson, N. M. (2018). Bargaining and the effectiveness of economic development incentives: An evaluation of the Texas Chapter 313 Program. Public Choice, 177 (1-2), 29-41.

Joshi, N. K. (2015). Party politics, governors, and healthcare expenditures. Economics and Politics, 27 (1), 53-77.

Ladd, H. (1994). Spatially targeted economic development strategies: Do they work? Cityscape: A Journal of Policy Development and Research, 1 (1), 193-218.

Layser, M. D. (2019). The pro-gentrification origins of place-based investment tax incentives and a path toward community oriented reform. Wisconsin Law Review, 2019 (4), 745-817. 
Layser, M. D. (2020). How Place-Based Tax Incentives Can Reduce Geographic Inequality. Tax Law Review, forthcoming.

Neumark, D., \& Kolko, J. (2010). Do enterprise zones create jobs? Evidence from California's Enterprise Zone Program. Journal of Urban Economics, 68 (1), 1-19.

Neumark, D., \& Simpson, H. (2014). Place-based policies. NBER Working Paper 20049. Cambridge, MA: National Bureau of Economic Research.

Nitti, Tony (2019). "IRS Releases Latest Round Of Opportunity Zone Regulations: Where Do We Stand Now?" Forbes Magazine, 22 April 2019, available online at: www.forbes.com/sites/anthonynitti/2019/04/22/irs-releases-latest-round-of-opportunityzone-regulations-where-do-we-stand-now/\#cbff45e 27727.

Novogradac, Michael (2018). "2017 Tax Legislation Creates New Tool for Community Development." Novoco, 1 February 2018, available online at: www.novoco.com/periodicals/articles/2017-tax-legislation-creates-new-tool-communitydevelopment.

Papke, L. (1994). Tax policy and urban development: Evidence from the Indiana Enterprise Zone Program. Journal of Public Economics, 54 (1), 37-49.

Peters, A. H., \& Fisher, P. S. (2002). State Enterprise Zone Programs: Have They Worked? Kalamazoo, MI: W.E. Upjohn Institute for Employment Research.

Peters, A. H., \& Fisher, P. S. (2004). The failures of economic development incentives. Journal of the American Planning Association, 70 (1), 27-37.

Pickering, A. C., \& Rockey, J. (2013). Ideology and the size of US state government. Public Choice, 156 (3-4), 443-465.

Potrafke, N. (2018). Government ideology and economic policy-making in the United States - A survey. Public Choice, 174 (1-2), 145-207.

Reynolds, C. L., \& Rohlin, S. (2014). Do location-based tax incentives improve quality of life and quality of business environment? Journal of Regional Science, 54 (1), 1-32.

Rosenthal, S. S. (2007). Old homes, externalities, and poor neighborhoods. A model of urban decline and renewal. Journal of Urban Economics, 63 (3), 816-840.

Theodos, B., González, J., \& Meixell, B. (2020). The opportunity zone incentive isn't living up to its equitable development goals. Here are four ways to improve it. Washington, D.C.: The Urban Institute, 17 June 2020, available online at: https://www.urban.org/urbanwire/opportunity-zone-incentive-isnt-living-its-equitable-development-goals-here-arefour-ways-improve-it.

Theodos, B. \& Meixell, B. (2018). Assessing Governor Brown's selections for opportunity zones in the Bay Area. Washington, D.C.: The Urban Institute, 18 May 2018, available online at: www.urban.org/urbanwire/assessing-governor-browns-selections-opportunity-zones-bayarea.

Theodos, B., Meisell, B., \& Hedman, C. (2018). Did states maximize their opportunity zone selections? Analysis of the opportunity zone designations. Washington, D.C.: The Urban Institute, 21 May 2018, available online at: https:/www.urban.org/research/publication/did-states-maximize-their-opportunity-zoneselections.

Tax Policy Center (2019). “What Are Opportunity Zones and How Do They Work?” Washington, D.C.: Tax Policy Center, available online at: www.taxpolicycenter.org/briefingbook/what-are-opportunity-zones-and-how-do-they-work. 
World Bank, The (2015). China's special economic zones. Washington, D.C.: The World Bank, available online at: www.worldbank.org/content/dam/Worldbank/Event/Africa/Investing $\% 20$ in $\% 20 \mathrm{Africa} \%$ 20Forum/2015/investing-in-africa-forum-chinas-special-economic-zone.pdf. 
Table 1 Summary statistics for all qualified opportunity zones from 2011-2015 ACS Survey

\begin{tabular}{lccc}
\hline & All Census & Potential & Designated \\
& Tracts, & QOZs, & QOZs, \\
& Mean & Mean & 1.000 \\
\hline Qualified Opportunity Zone & 0.106 & 0.244 & 143.639 \\
Median House Value (in \$1000s) & 227.744 & 154.979 & 0.136 \\
Unemployment Rate & 0.089 & 0.120 & 34.316 \\
Median Household Income (in \$1000s) & 58.668 & 37.731 & 4.041 \\
Population (in 1000s) & 4.402 & 4.058 & 0.229 \\
Proportion with Less Than High School Diploma & 0.140 & 0.215 & 0.165 \\
Proportion with At Least 4-year Degree & 0.286 & 0.178 & 0.267 \\
Proportion Black & 0.133 & 0.224 & 0.220 \\
Proportion Hispanic & 0.158 & 0.231 & 0.013 \\
Proportion Native American & 0.007 & 0.011 & 0.242 \\
Proportion Under 18 (in years) & 0.227 & 0.239 & 0.130 \\
Proportion Over 65 (in years) & 0.149 & 0.133 & 0.596 \\
Proportion of Tract Represented by Democrat (Lower) & 0.467 & 0.594 & 0.540 \\
Proportion of Tract Represented by Democrat (Upper) & 0.444 & 0.545 & 0.530 \\
Legislature-Governor Partisan Match (Lower) & 0.559 & 0.517 & 0.533 \\
Legislature-Governor Partisan Match (Upper) & 0.571 & 0.529 & 0.281 \\
Proportion on Welfare & 0.150 & 0.245 & 0.758 \\
In Metropolitan Area (Yes=1; No=0) & 0.834 & 0.801 & 0.123 \\
Higher Education Campus (Yes=1; No=0) & 0.076 & 0.090 & 7410 \\
\hline Observations & 69,921 & 29,549 & \\
\hline
\end{tabular}

Notes: Asterisks represent the difference-in-means test between nominated and designated OZs, with ${ }^{*} p<0.10,{ }^{* *} p$ $<0.05$, and ${ }^{* * *} p<0.01$. 
Table 2 Marginal effects from logit regressions

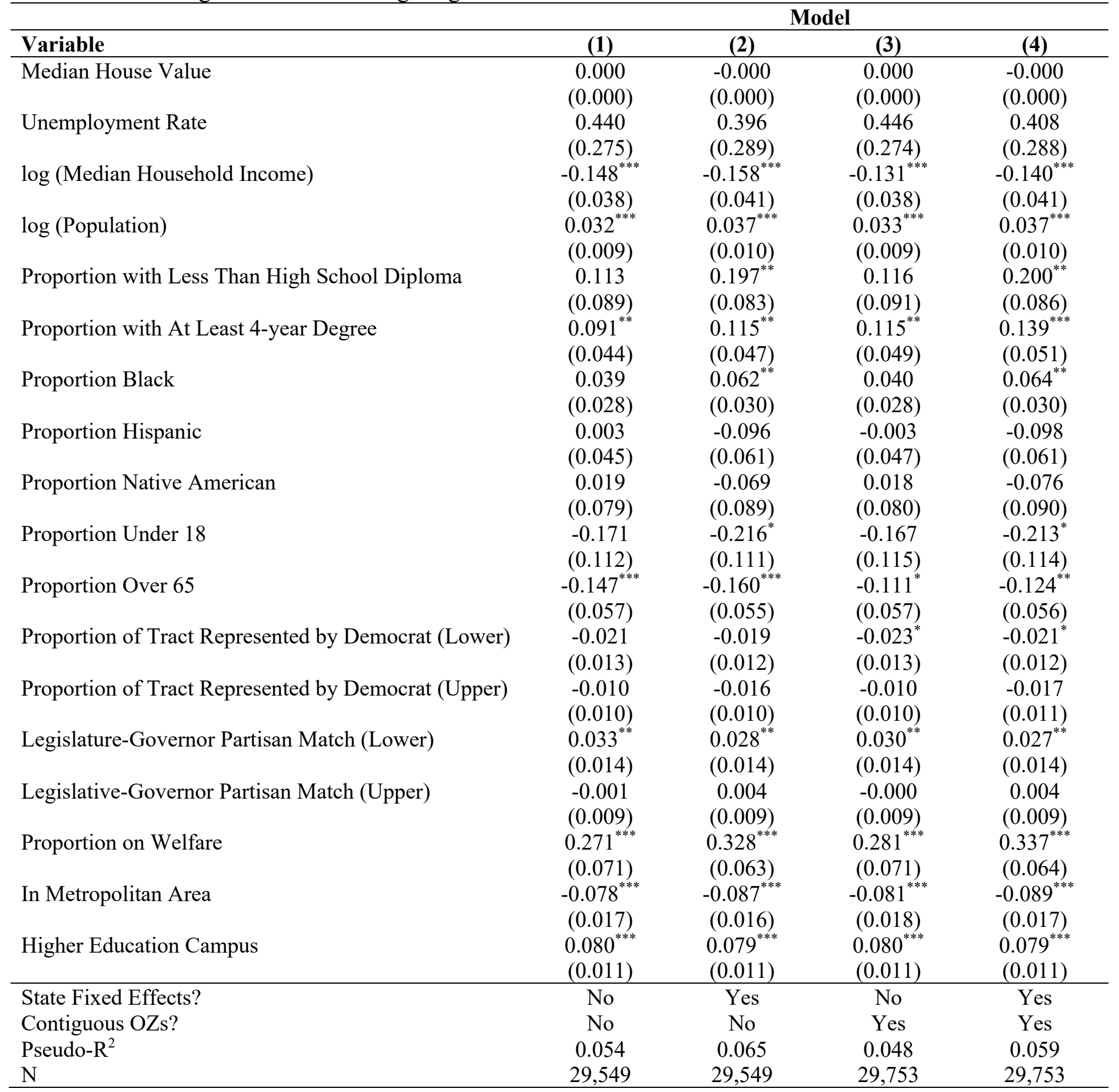

Notes: Marginal effects are reported with standard errors in parentheses, where $\Delta$ is a discrete change of a dummy variable from 0 to 1 . Note that the difference in observations for specifications (1) and (2) versus specifications (3) and (4) is due to adding to specifications (3) and (4) 170 observations from non-LIC tracts contiguous to an LIC, 32 observations that meet LIC requirements but are not listed as LICs by IRS, and 2 observations that are "suspicious". ${ }^{*} p<0.10,{ }^{* *} p<0.05,{ }^{* * *} p<0.01$. 
Table 3 Estimation results from linear probability models

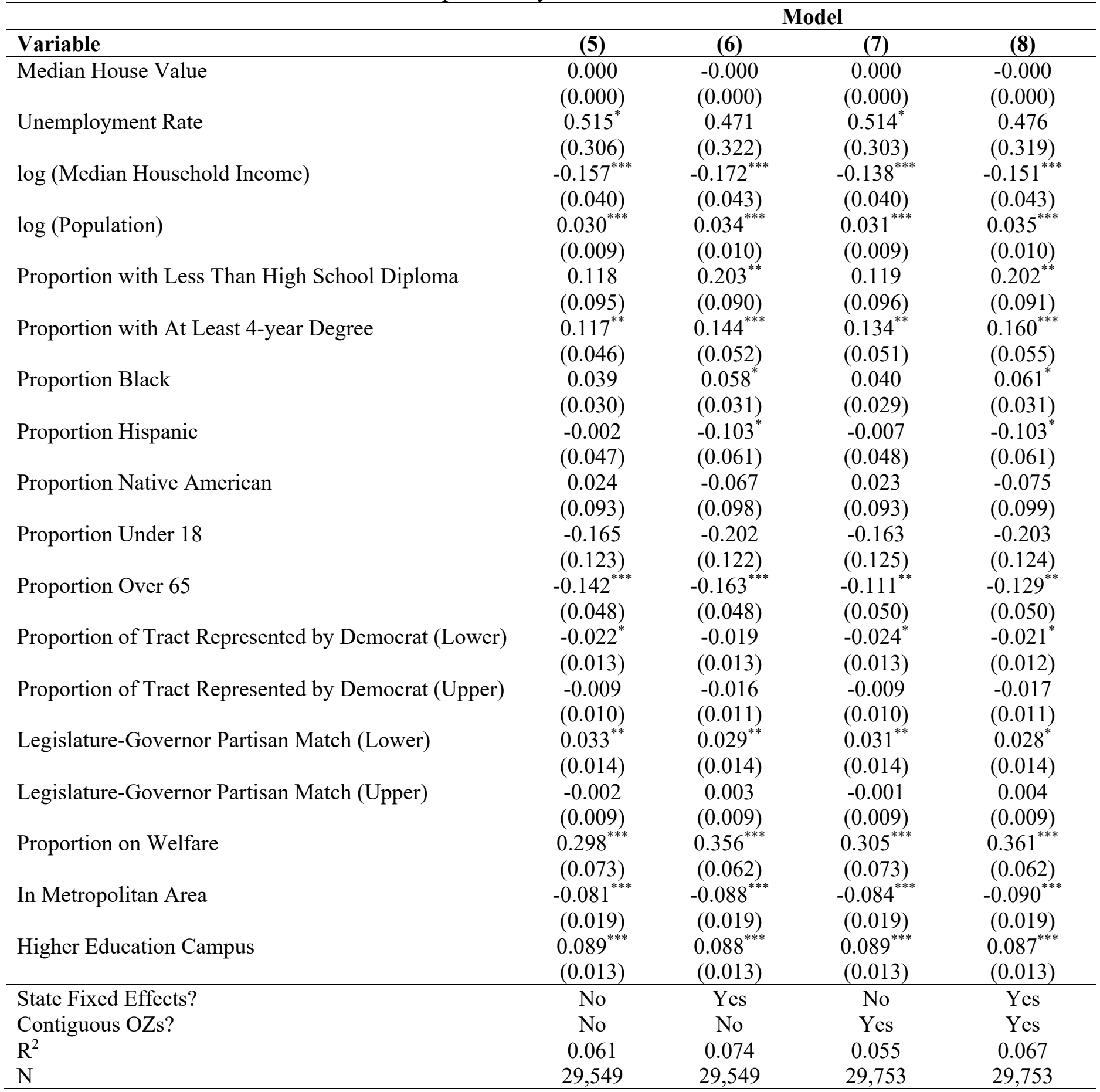

Notes: Standard errors are in parentheses. Note that the difference in observations for specifications (5) and (6) versus specifications (7) and (8) is due to adding to specifications (7) and (8) 170 observations from non-LIC tracts contiguous to an LIC, 32 observations that meet LIC requirements but are not listed as LICs by IRS, and 2 observations that are suspicious. ${ }^{*} p<0.10,{ }^{* *} p<0.05,{ }^{* * *} p<0.01$. 
Table 4 Marginal effects from logit regressions on samples split by executive partisanship

\begin{tabular}{|c|c|c|}
\hline \multirow[b]{3}{*}{ Variable } & \multicolumn{2}{|c|}{ Model } \\
\hline & (9) & (10) \\
\hline & $\begin{array}{c}\text { States with Republican } \\
\text { Governors }\end{array}$ & $\begin{array}{c}\text { States with Democrat } \\
\text { Governors }\end{array}$ \\
\hline \multirow[t]{2}{*}{ Median House Value } & 0.000 & $-0.000^{*}$ \\
\hline & $(0.000)$ & $(0.000)$ \\
\hline \multirow[t]{2}{*}{ Unemployment Rate } & 0.578 & 0.112 \\
\hline & $(0.434)$ & $(0.158)$ \\
\hline \multirow[t]{2}{*}{$\log$ (Median Household Income) } & $-0.117^{* *}$ & $-0.168^{* * *}$ \\
\hline & $(0.046)$ & $(0.063)$ \\
\hline \multirow[t]{2}{*}{$\log$ (Population) } & $0.044^{* * *}$ & $0.025^{*}$ \\
\hline & $(0.015)$ & $(0.014)$ \\
\hline \multirow[t]{2}{*}{ Proportion with Less Than High School Diploma } & $0.207^{* *}$ & 0.130 \\
\hline & $(0.103)$ & $(0.084)$ \\
\hline \multirow[t]{2}{*}{ Proportion with At Least 4-year Degree } & 0.086 & $0.212^{* * *}$ \\
\hline & $(0.063)$ & $(0.066)$ \\
\hline \multirow[t]{2}{*}{ Proportion Black } & 0.029 & 0.078 \\
\hline & $(0.041)$ & $(0.053)$ \\
\hline \multirow[t]{2}{*}{ Proportion Hispanic } & $-0.221^{* * * *}$ & 0.055 \\
\hline & $(0.043)$ & $(0.059)$ \\
\hline \multirow[t]{2}{*}{ Proportion Native American } & $-0.212^{* *}$ & 0.149 \\
\hline & $(0.097)$ & $(0.124)$ \\
\hline \multirow[t]{2}{*}{ Proportion Under 18} & $-0.258^{* *}$ & -0.147 \\
\hline & $(0.117)$ & $(0.182)$ \\
\hline \multirow[t]{2}{*}{ Proportion Over 65} & $-0.135^{*}$ & -0.091 \\
\hline & $(0.075)$ & $(0.113)$ \\
\hline \multirow[t]{2}{*}{ Proportion of Tract Represented by Democrat (Lower) } & $-0.034^{* *}$ & -0.008 \\
\hline & $(0.016)$ & $(0.018)$ \\
\hline \multirow[t]{2}{*}{ Proportion of Tract Represented by Democrat (Upper) } & -0.010 & -0.013 \\
\hline & $(0.017)$ & $(0.014)$ \\
\hline \multirow[t]{2}{*}{ Proportion on Welfare } & $0.307^{* * *}$ & $0.420^{* * *}$ \\
\hline & $(0.058)$ & $(0.084)$ \\
\hline \multirow[t]{2}{*}{ In Metropolitan Area } & $-0.087^{* * *}$ & $-0.092^{* * *}$ \\
\hline & $(0.022)$ & $(0.029)$ \\
\hline \multirow[t]{2}{*}{ Higher Education Campus } & $0.074^{* * *}$ & $0.085^{* * *}$ \\
\hline & $(0.015)$ & $(0.015)$ \\
\hline State Fixed Effects? & Yes & Yes \\
\hline Contiguous OZs? & Yes & Yes \\
\hline Pseudo-R ${ }^{2}$ & 0.061 & 0.063 \\
\hline $\mathrm{N}$ & 17,033 & 12,720 \\
\hline
\end{tabular}

Notes: Marginal effects are presented with standard errors in parentheses, where $\Delta$ is a discrete change of a dummy variable from 0 to $1 .{ }^{*} p<0.10,{ }^{* *} p<0.05,{ }^{* * *} p<0.01$. 
Table 5 Estimation results from a restricted sample including only tracts with one representative

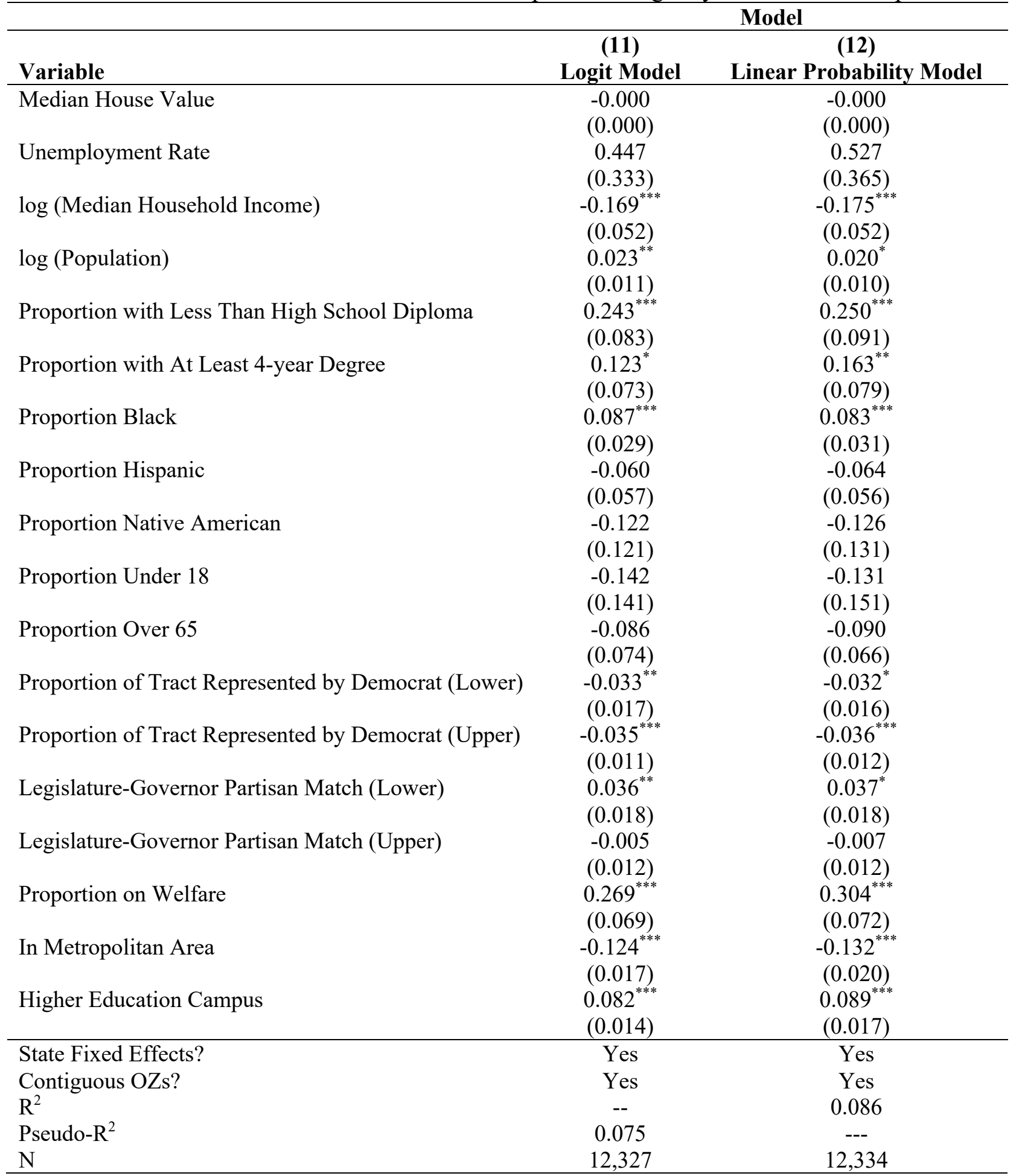

Notes: Marginal effects are presented with standard errors in parentheses, where $\Delta$ is a discrete change of a dummy variable from 0 to $1 .{ }^{*} p<0.10,{ }^{* *} p<0.05,{ }^{* * *} p<0.01$. 
Table 6 Summary statistics for "suspicious" opportunity zones

\begin{tabular}{lcccc}
\hline Variable & Mean & Standard Deviation & Minimum & Maximum \\
\hline Qualified Opportunity Zone & 1.000 & 0.000 & 1.000 & 1.000 \\
Median House Value & 147.777 & 117.013 & 47.814 & 584.197 \\
Unemployment Rate & 0.068 & 0.087 & 0.000 & 0.500 \\
Median Household Income & 50.746 & 15.471 & 31.069 & 95.497 \\
Population & 2.635 & 1.964 & 0.000 & 7.579 \\
Proportion with Less Than High School Diploma & 0.126 & 0.106 & 0.000 & 0.500 \\
Proportion with At Least 4-year Degree & 0.295 & 0.202 & 0.000 & 0.760 \\
Proportion Black & 0.146 & 0.210 & 0.000 & 0.852 \\
Proportion Hispanic & 0.105 & 0.225 & 0.000 & 1.000 \\
Proportion Native American & 0.012 & 0.030 & 0.000 & 0.156 \\
Proportion Under 18 & 0.159 & 0.095 & 0.000 & 0.334 \\
Proportion Over 65 & 0.157 & 0.093 & 0.000 & 0.314 \\
Proportion of Tract Represented by Democrat (Lower) & 0.490 & 0.500 & 0.000 & 1.000 \\
Proportion of Tract Represented by Democrat (Upper) & 0.498 & 0.486 & 0.000 & 1.000 \\
Legislature-Governor Partisan Match (Lower) & 0.421 & 0.500 & 0 & 1 \\
Legislature-Governor Partisan Match (Upper) & 0.447 & 0.504 & 0 & 1 \\
Proportion on Welfare & 0.023 & 0.019 & 0.000 & 0.067 \\
In Metropolitan Area & 0.605 & 0.495 & 0 & 1 \\
Higher Education Campus & 0.079 & 0.273 & 0 & 1 \\
\hline Observations & 38 & 38 & 38 & 38 \\
\hline
\end{tabular}


Table 7 Cross-tabulations for "suspicious" opportunity zones

\begin{tabular}{lcccc}
\hline State & $\begin{array}{c}\text { OZ is nominated when } \\
\text { LIC does not meet criteria }\end{array}$ & $\begin{array}{c}\text { Contiguous non-LIC tract } \\
\text { is not adjacent to OZ }\end{array}$ & $\begin{array}{c}\text { OZ is not } \\
\text { populated in ACS }\end{array}$ & Total \\
\hline Arkansas & 3 & 0 & 0 & 3 \\
California & 1 & 0 & 0 & 1 \\
Colorado & 1 & 0 & 0 & 1 \\
Connecticut & 1 & 0 & 0 & 1 \\
Florida & 1 & 0 & 1 & 2 \\
Illinois & 1 & 0 & 0 & 1 \\
Iowa & 3 & 0 & 0 & 3 \\
Kansas & 1 & 0 & 0 & 1 \\
Kentucky & 1 & 0 & 0 & 1 \\
Maine & 1 & 0 & 0 & 1 \\
Maryland & 1 & 0 & 1 & 1 \\
Michigan & 4 & 0 & 0 & 5 \\
Minnesota & 2 & 0 & 0 & 2 \\
Montana & 1 & 0 & 0 & 1 \\
Nebraska & 1 & 0 & 0 & 1 \\
Nevada & 1 & 0 & 0 & 1 \\
New York & 1 & 0 & & 1 \\
North & 1 & 0 & 0 & 1 \\
Carolina & & & 0 & 5 \\
Oklahoma & 4 & 1 & 0 & 1 \\
Pennsylvania & 1 & 0 & 0 & 1 \\
Puerto Rico & 1 & 0 & 0 & 2 \\
South & 2 & 0 & & \\
Carolina & & 0 & & 38 \\
Texas & 15 & 1 & 0 & \\
\hline Observations & & & 0 & \\
\hline & & 0 & 0 & \\
\hline
\end{tabular}


Figure 1 Map of designated opportunity zones

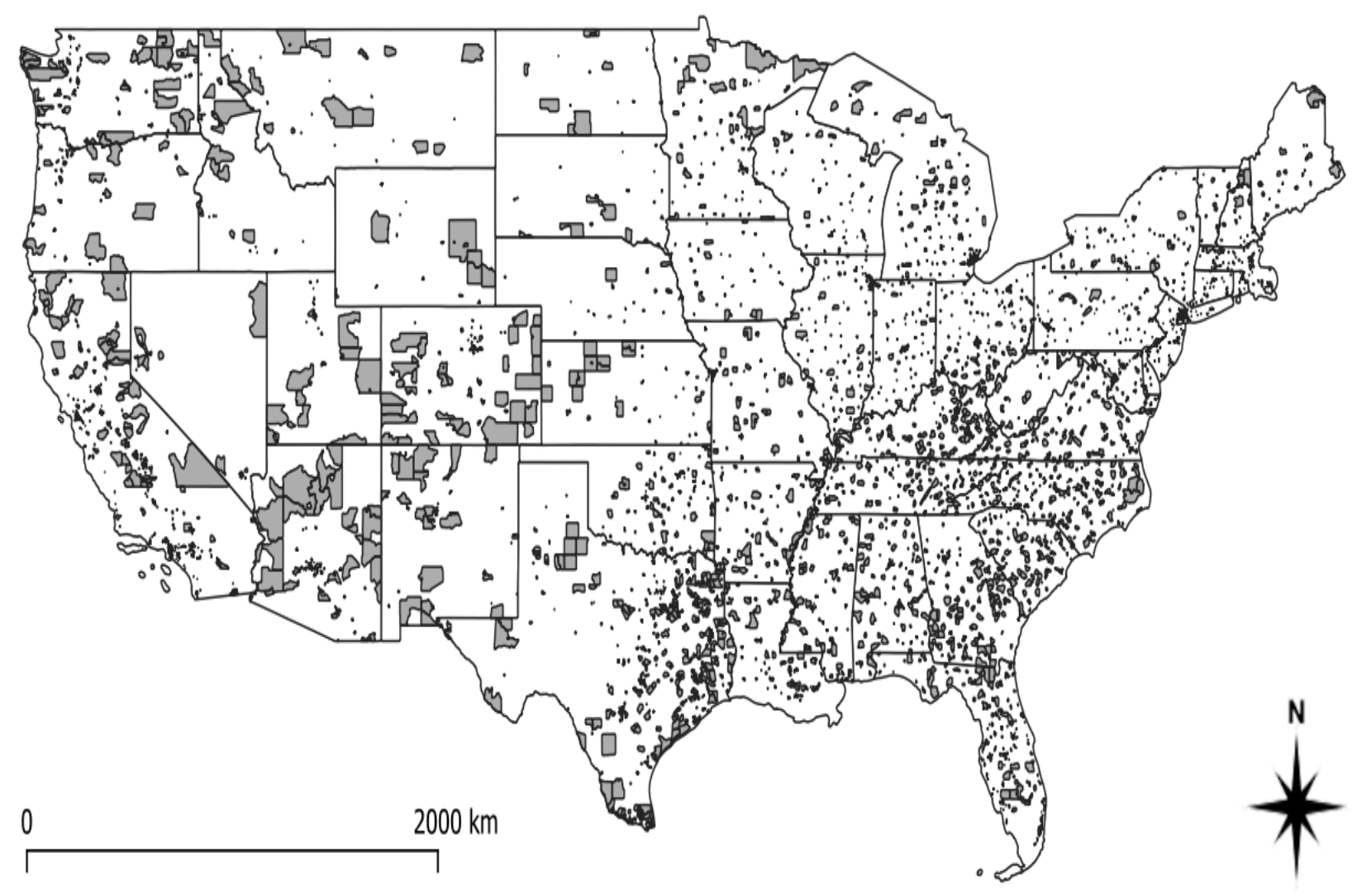

